\title{
Macrozoobenthos of the Pechora Sea (SE Barents Sea): community structure and spatial distribution in relation to environmental conditions
}

\author{
S. G. Denisenko ${ }^{1,3, *}$, N. V. Denisenko ${ }^{1,3}$, K. K. Lehtonen ${ }^{2}$, A.-B. Andersin' ${ }^{2}$, A. O. Laine ${ }^{2}$ \\ ${ }^{1}$ Murmansk Marine Biological Institute, 17 Vladimirskaya St., 183010 Murmansk, Russia \\ ${ }^{2}$ Finnish Institute of Marine Research, PO Box 33, 00931 Helsinki, Finland \\ ${ }^{3}$ Present address: RAS Zoological Institute, Universitetskaya nab. 1, 199034 St. Petersburg, Russia
}

\begin{abstract}
Extensive investigations on macrozoobenthic communities of the Pechora Sea (SE Barents Sea), carried out between 1991 and 1995, indicate that it is rich in terms of diversity, with a total of 712 taxa observed (505 identified to species level). Biomass distribution of zoobenthos varied greatly (2.6 to $1200 \mathrm{~g} \mathrm{~m}^{-2}$ wet wt). Average values recorded for the offshore areas are high for an Arctic environment, implying that the influence of the large Pechora River may extend far into the offshore area. In addition, intensive sedimentation of organic matter during the retreat of the highly productive ice-edge zone in the summer may also contribute to the observed high biomass. A method combining the abundance and biomass values of species was used to calculate an index approximating the production of each species. This index was used to distinguish the different community types in the area. In the study area, 13 benthic community types were identified, of which 2 main types covered most of the offshore areas. The concentration of total organic carbon (TOC) in the sediment was shown to have a strong influence on the diversity of the benthic communities, while both TOC and water depth affected the distribution of communities and the feeding mode of the dominant species. A community type consisting of surface deposit-feeders is the most widely distributed type in the area. Suspension feeders, however, dominate an extensive shallow offshore area. Boreal-Arctic species show a marked predomination $(68.9 \%)$ in the whole Pechora Sea. The share of Arctic species is greater in the northern part influenced by cold water currents, while boreal species predominate in areas affected by warmer coastal waters. These observations indicate that the Pechora Sea functions as a transitional zone between boreal and Arctic biogeographic regions.
\end{abstract}

KEY WORDS: Arctic • Biogeography · Community structure · Diversity · Macrozoobenthos · Pechora Sea

\section{INTRODUCTION}

The Barents Sea is one of the best-described marine areas in the Arctic. The SE part, the Pechora Sea, is considered to be a separate sea area because of marked differences in environmental conditions compared to the rest of the Barents Sea, e.g. a strong influence of river runoff, relative shallowness and variability in salinity and temperature (Tereschenko et al. 1985, Milliman \& Syvitski 1992). The area is an important spawning area for Arctic fishes, and is rich in sea birds (both ducks and gulls) and mammals (e.g. walrus) (Nikiforov \& Mescherskaya 1999) that feed on benthic organisms. The discovery of rich offshore oil and gas deposits in the seabed of the area, and the ensuing development of field exploitation in combination with the intensive maritime traffic along the Northern Shipping Route, poses a major threat to the ecological balance of this Arctic environment. Therefore, detailed basic information about the area's ecosystem is important.

During Soviet times, large amounts of Russian data and publications were, in practice, inaccessible for the 
international scientific community, hindering the distribution of scientific knowledge; this is also true for the information concerning the Pechora Sea. As for zoobenthos, the first quantitative investigations were accomplished already in the 1920s, resulting in the classic publication of Brotskaya \& Zenkevich (1939). The material collected during later surveys, carried out in 1959 and 1970, has only partly been used in publications by different authors (Galkin 1964, Khodkina 1964, Streltzov 1966, Antipova 1973). In the beginning of the 1990s, modern methods to determine macrozoobenthic associations and to estimate their relationships with environmental factors in the Pechora Sea were applied by Dahle et al. (1998). This study was, however, based only on a small number of sampling stations, and the methods used were incomparable with previous Russian studies.

The current study presents the largest and most comprehensive data existing from the Pechora Sea area. The data were collected during several expeditions between 1991 and 1995 by the Murmansk Marine Biological Institute (MMBI), the Finnish Institute of Marine Research (FIMR), the Russian Institute of Ocean Geology (RIOG), and the Zoological Institute/Russian Academy of Science, St. Petersburg (ZISP). These data sets form an extensive station network that covers practically the entire Pechora Sea basin, providing a good basis for revision of the earlier community determinations. In the present study, a 'universal' production approach is used to determine the different benthic assemblages, and their distribution in relation to environmental conditions is investigated. In addition, the biogeographic status of the Pechora Sea macrozoobenthos is revised.
Oceanography and ice conditions: The Pechora Sea forms a mixing zone of 4 main water masses: (1) coastal freshwater run-off in the south, (2) Atlantic water in the central part, (3) Barents Sea water in the Prinovozemelskiy Trough, and (4) Arctic water intruding from the Kara Gate strait and flowing northwards along the coast of the Novaya Zemlya (Ilyin \& Matishov 1992, also concisely reviewed in Dahle et al. 1998).

Temperature and salinity of both surface and bottom water layers show distinct seasonal and spatial variations (Adrov \& Denisenko 1996). The temperature of the bottom water is generally $<0^{\circ} \mathrm{C}$ in most parts of the basin until early June, and reaches maximum values in August/September, from $-1^{\circ} \mathrm{C}$ in the north to $+6^{\circ} \mathrm{C}$ in the southwest near the mainland. Average nearbottom salinity in the offshore area ranges from 34 PSU in winter to 26-31 PSU in late June. The summer decrease in salinity is marked due to ice-melt and the extensive run-off of freshwater from the large Pechora River, which is responsible for ca. $80 \%$ of the total river water input to the whole Barents Sea (Milliman \& Syvitski 1992). The Pechora Sea is annually covered by ice during 8 mo (Gorshkov 1980, Adrov \& Denisenko 1996). The ice starts to form in the beginning of October, and completely disappears by late July.

Primary production in the Pechora Sea is strongly limited to the ice-free months. Estimates of the amount of organic matter produced have been considered typical for Arctic areas (Savinov 1997, Vinogradov et al. 2000). However, recent studies imply that in early summer, during the melting and the retreat of ice, the ice-edge zone is highly productive (Makarevich 1998, Falk-Petersen et al. 2000), probably leading to

\section{MATERIALS AND METHODS}

Study area. The Pechora Sea is located in the SE Barents Sea and occupies roughly $117000 \mathrm{~km}^{2}$ (ca. $10 \%$ of the whole Barents Sea) (Fig. 1). The Pechora Sea differs from the rest of the Barents Sea because of its shallowness, with only 1 markedly deep area, the 180 to $210 \mathrm{~m}$ deep Prinovozemelskiy Trough south of Novaya Zemlya.

In regard to anthropogenic impacts, the area represents a relatively undisturbed environment. No significant concentrations of environmental contaminants in sediments, known to have a structuring effect on benthic communities (e.g. Warwick et al. 1987, Gray et al. 1990), have been recorded (Loring et al. 1995).

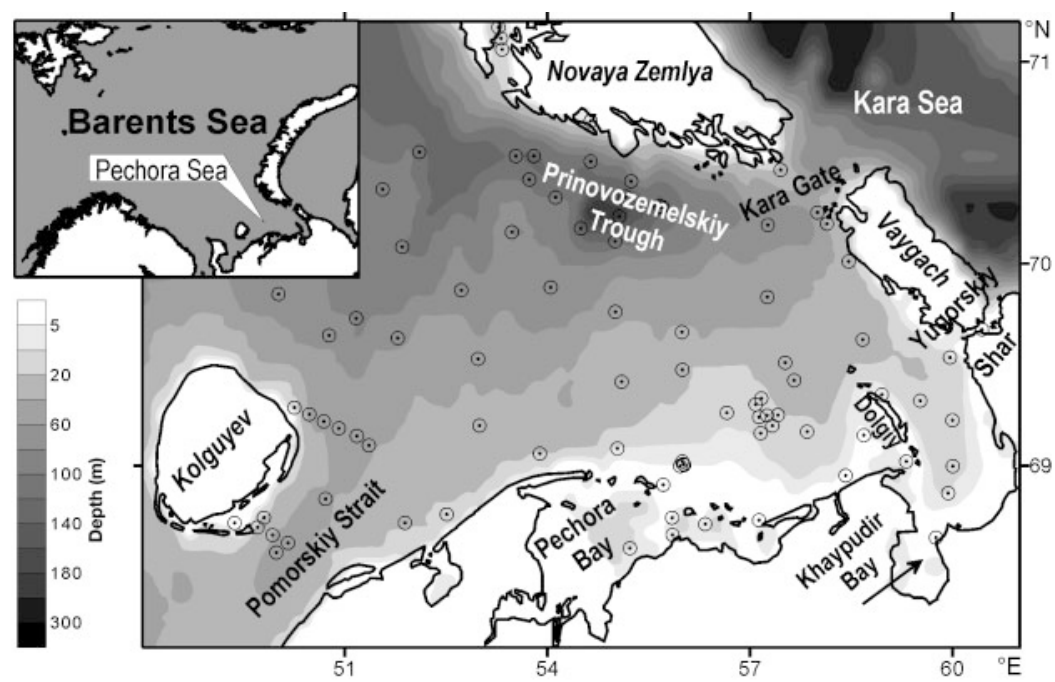

Fig. 1. Macrozoobenthic sampling stations $(\odot)$ in the Pechora Sea from 1991 to 1995 
an increased sedimentation of high-quality food for benthic feeders.

Sediment characteristics and organic carbon content: Considering sediment quality, the Pechora Sea is a heterogeneous area (Klenova 1960, Adrov \& Denisenko 1996, reviewed in Dahle et al. 1998) (Appendix 1, available at www.int-res.com/journals/suppl/denisenkoappendix.pdf). In the NW part of the Pechora Sea the bottoms are characterised by soft mud with scattered patches of mixed sediments. The sea floor of the Pomorskiy Strait consists mainly of fine muddy sediments. The shallow coastal bottoms at depths $<50 \mathrm{~m}$ are relatively homogeneous with muddy sand and patches of clayey mud towards the north and east of the Pechora Bay. In the areas around the Dolgiy Island, the northern part of Vaygach Island and the southernmost part of Novaya Zemlya, at depths $>15 \mathrm{~m}$, the bottoms consist of fine mud with a slight admixture of gravel.

Previous data (Gorshkova 1957, Gurevich 1976, Loring et al. 1995) and samples collected during the present study were used to create an updated map of total organic carbon (TOC) concentrations in the surface sediments of the Pechora Sea area (Fig. 2). The TOC levels vary markedly, with the sediments in the deep Prinovozemelskiy Trough, the shallow depressions in the NE part of the Pomorskiy Strait, and the northeast of the Kolguyev Island containing the highest values $(>1 \%)$. Because of the weak water circulation in the near-bottom layer, the sediment surface in these areas consists of brown mud with high water content. In con-

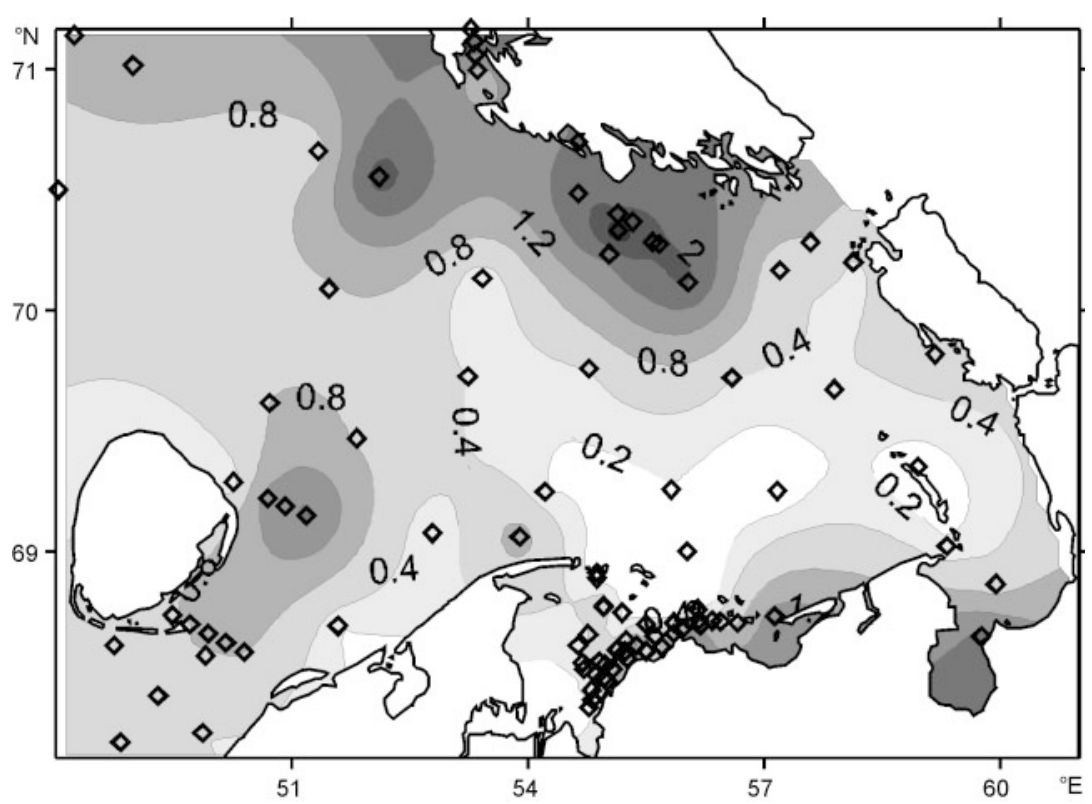

Fig. 2. Total organic carbon; (TOC; \%) in surface sediments of the Pechora Sea, based on measurements during the present study and earlier studies by Gorshkova (1957), Gurevich (1976) and Loring et al. (1995). Positions of stations used for mapping the content of organic carbon are indicated $(\diamond)$ trast, due to the constant currents, tide and waves, the sandy sediments of the southern shallow-water areas contain only small amounts of TOC $(<0.1 \%)$.

Field work. During the summers of 1991 to 1995, quantitative sampling of zoobenthos was carried out at 87 stations in the Pechora Sea (Fig. 1, Appendix 1, available at www.int-res.com/journals/suppl/denisenkoappendix.pdf). Most of them (72) were sampled between 1992 and 1993 in the offshore area on expeditions of RV 'Professor Kurentsov' (Cruise 1992a) and RV 'Delniye Zelentsy' (Cruises 1992b and 1993). Earlier, in 1991, 6 stations had been visited during a cruise of RV 'Akademik Karpinsky', and in 1995, 6 additional stations were investigated aboard RV 'Professor Kuznetsov' (Cruise 1995a) and 3 more aboard RV 'Geophizik' (Cruise 1995b). The depth of the sampling stations varied from 9 to $206 \mathrm{~m}$.

Quantitative samples were taken with a $0.25 \mathrm{~m}^{2}$ ocean grab (Lisitsin \& Udintsev 1955, 2 replicates) or a $0.1 \mathrm{~m}^{2}$ van Veen grab (van Veen 1933, 5 replicates). Although the 2 grab types do not have the same weight and biting areas, they penetrate the sediment similarly. An empirical comparison of the species composition obtained by using the 2 grab types showed a similar level of species richness (Denisenko 1992). At selected stations, additional samples were collected with a $1 \mathrm{~m}$ wide sediment dredge to check the reliability of the grab samples regarding species composition.

In 1991-92, the samples were sieved through a stainless steel net (1.0 mm mesh size), while in 1993 and 1995 a nylon net bag $(0.75 \mathrm{~mm})$ was used. Macrobenthic animals were fixed in $4 \%$ formaldehyde buffered by sodium tetraborate.

Laboratory work. The animals were sorted under a binocular microscope into main systematic groups and preserved in $70 \% \mathrm{EtOH}$ for later identification to species (or to the lowest feasible taxonomic) level. The species identified in each sample were counted. Alcohol wet weight (wet wt) was used as the biomass indicator because the drying of the specimens would have resulted in an undesired loss of valuable taxonomic material. The use of alcohol wet wt also enables the comparison of the results with previously published data (e.g. Brotskaya \& Zenkevich 1939). Molluscs, bryozoans and barnacles were weighed with their exoskeleton. Annelids were removed from their tubes before weighing (except for the long-tubed polychaete Spiochaetopterus typicus). Mobile, large epiben- 
thic species occurred seldom in the samples and were excluded from the analyses.

Calculations. Diversity was expressed by the Shannon-Wiener index $H^{\prime}$ (Shannon \& Weaver 1949), based on mean abundances calculated for the different stations.

The approximate production of a species per year or growth season, hereafter referred to as 'relative production' $\left(P_{\mathrm{s}}\right)$, was calculated using the following equation:

$$
P_{\mathrm{s}}=B_{\mathrm{s}}^{0.75} \times N_{\mathrm{s}}^{0.25}
$$

where $B_{\mathrm{s}}=$ biomass (g wet wt $\mathrm{m}^{-2}$ ) and $N_{\mathrm{s}}=$ abundance (ind. $\mathrm{m}^{-2}$ ) of species ' $\mathrm{s}$ '. In regard to 'true' production values, this equation gives a rough estimate sometimes, but it is practical for community determination purposes.

For calculating similarity between stations, the Czekanowski-Sorensen index (Cz) (Czekanowski 1909, Sorensen 1948) was applied. The relative production value of each taxon was used in the calculations as follows:

$$
\mathrm{Cz}=2 \times \mathrm{S}\left[\min \left(P_{\mathrm{sa}}, P_{\mathrm{sb}}\right)\right] / \mathrm{S}\left[\left(P_{\mathrm{sa}}+P_{\mathrm{sb}}\right)\right]
$$

where $P_{\mathrm{sa}}$ and $P_{\mathrm{sb}}=$ relative production $\left(\mathrm{m}^{-2}\right)$ of the species $\mathrm{s}$ at Stns a and b, respectively, and $\mathrm{min}=$ minimum.

The determination of zoobenthic communities was carried out using a standard hierarchical clustering procedure on data obtained from each station using the average linkage method (e.g. Pesenko 1982) of 'Primer' and 'BioDiversity Pro' softwares (BioDiversity Professional Version 2 [1998], ${ }^{\circ}$ The Natural History Museum \& the Scottish Association for Marine Science; PRIMER 4.0 [1994], Plymouth Marine Laboratory [NERC]). To determine the level at which the samples should be assigned to separate communities, average similarity was calculated for the whole zoobenthos data matrix (Sirotinskaya 1975).

The significance of a species in a community is expressed here by introducing the term 'Species Validity Index' (SVI), calculated by multiplying the relative production value with the frequency of occurrence of a species at the stations. Further, to study the functional aspects of the different communities, the main feeding type of each community was determined by identifying the feeding mode of the 15 most dominant species ranked according to the SVI.

The influence of environmental factors on spatial distribution of the zoobenthic communities was studied using the Classification Tree method (SYSTAT ${ }^{\circledR} 9.0$ [1998], SPSS). The selected environmental parameters included average summer values recorded between 1957 and 1987 of (1) near-bottom and (2) integrated total water column temperature, (3) near-bottom and
(4) surface water salinity, and (5) near-bottom oxygen levels, as well as (6) concentration of TOC in the sediment and (7) station depth. In addition to the data collected during this study, supplementary data needed for the statistical analyses were obtained from the CDROM 'Climatic atlas of the Barents Sea' (MMBI-NOAA 1998) and from the literature (Gorshkova 1957, Loring et al. 1995, Adrov \& Denisenko 1996).

Biogeographic analyses. The boundaries of the main biogeographic regions in the Atlantic were taken from Ekman (1953) and Golikov (1982). Biogeographic terminology combines the geographical origin of the species (Atlantic, Pacific, Arctic) with the biogeographic zonation of the ocean (boreal, Arctic, boreal-Arctic) and the latitudinal zones of occurrence (wide-spread, high boreal, etc.) (e.g. Golikov 1982). For the present work, the biogeographic characteristics of zoobenthic species were obtained from Anisimova (1989), Fedyakov \& Naumov (1989), Gontar \& Denisenko (1989), Denisenko \& Galkin (1996) and Frolova (1996).

\section{RESULTS}

\section{Species composition and diversity}

A total of 712 macrozoobenthic taxa were recorded, of which 505 taxa were identified to species level (Table 1). Groups not listed in Table 1, such as foraminifers, sponges, nematodes, nemertins, sipunculids and tunicates, were mainly determined to genus (or higher) level only. A distinctly low number of taxa (10 to 20) was observed in the deepest region of the Prinovozemelskiy Trough, at 189 to $210 \mathrm{~m}$ depth in very soft sediments with a high water content, and also near the mouths of the Pechora and Khaypudir Bays in zones characterized by muddy sand sediments and/or a strong influence of freshwater. In the shallow sandybottom areas of the central and southern regions, the number of taxa was comparatively high (50 to 65 ).

Table 1. Number of macrozoobenthic taxa and species identified in the samples collected from the Pechora Sea

\begin{tabular}{|lcc|}
\hline Taxon & $\begin{array}{c}\text { Total no. } \\
\text { of taxa }\end{array}$ & $\begin{array}{c}\text { No. identified to } \\
\text { species level }\end{array}$ \\
\hline Polychaeta & 176 & 127 \\
Mollusca & 139 & 101 \\
Gastropoda & 62 & 49 \\
Bivalvia & 66 & 50 \\
Crustacea & 157 & 129 \\
Amphipoda & 101 & 80 \\
Bryozoa & 120 & 71 \\
Echinodermata & 27 & 22 \\
Cnidaria & 40 & 29 \\
Other & 53 & - \\
\hline
\end{tabular}




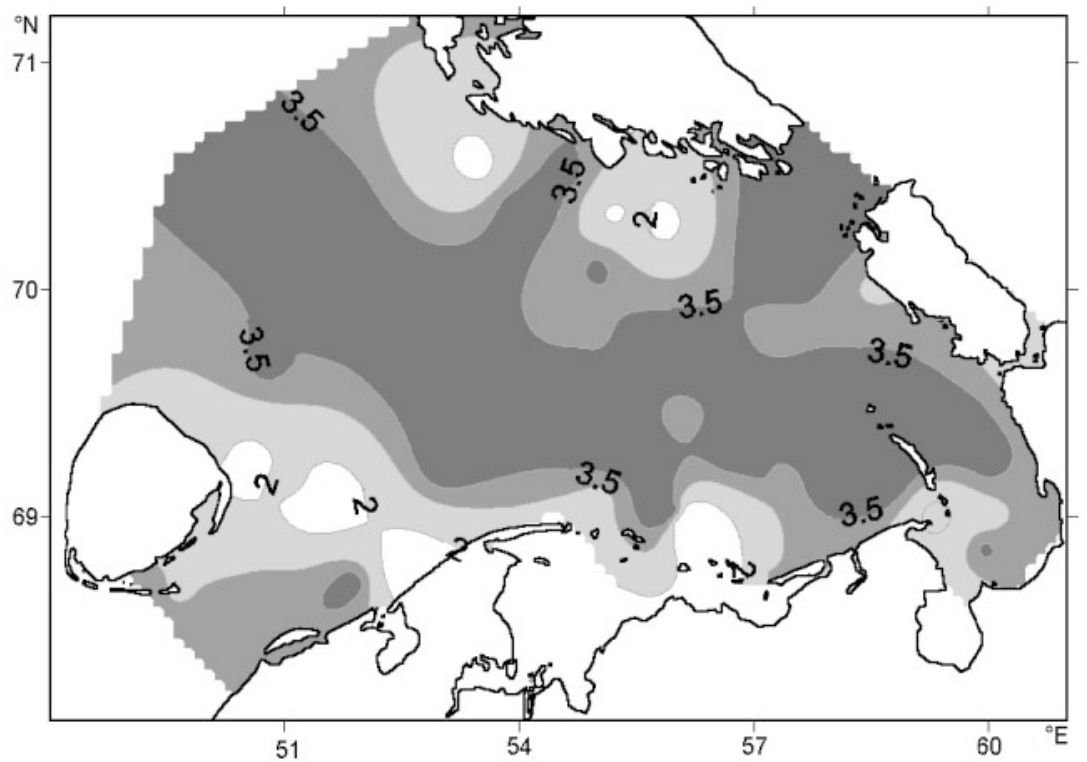

Fig. 3. Diversity of macrozoobenthos (Shannon-Wiener $H^{\prime}$ ) in the Pechora Sea

Macoma spp. ( 250 to 650 ind. $\left.\mathrm{m}^{-2}\right)$. Among other systematic groups, the highest abundance was observed in echinoderms, while crustaceans are not among the dominant groups in the Pechora Sea.

Compared to abundance, biomass varied even more between stations (1.5 to $536 \mathrm{~g}$ wet wt $\mathrm{m}^{-2}$, Fig. 4). Particularly high biomass values (>500 $\mathrm{g}$ wet $\mathrm{wt}$ $\mathrm{m}^{-2}$ ) were recorded in the NW region at depths of $\sim 100 \mathrm{~m}$, and in the SW part of the sea $\left(\sim 350\right.$ ot $400 \mathrm{~g}$ wet $\left.\mathrm{wt} \mathrm{m}^{-2}\right)$. On shallow, sandy erosion bottoms close to the Pechora Bay, very low values $(\sim 30 \mathrm{~g}$ wet wt $\mathrm{m}^{-2}$ ) were recorded. Molluscs dominate overwhelmingly the benthic biomass in the Pechora Sea, with polychaetes forming the second largest group. The distribution of molluscan biomass showed high values between the Kolguyev Island and Novaya

Diversity was high $\left(H^{\prime}>3\right)$ in most parts of the Pechora Sea (Fig. 3). The highest diversity $\left(H^{\prime}>5\right)$ was observed on bottoms with mixed sediments including harder fractions (pebbles, gravel), mostly in the northwest and in the Kara Gate strait area. Areas with $H^{\prime}<2$ were observed near the Kolguyev Island and in the bay mouths directly influenced by freshwater from the mainland rivers.
Zemlya. The highest polychaete biomass values were observed in the deep Prinovozemelskiy Trough, where they also dominated the biomass. High polychaete biomass values were also found in the NW part of the sea. Echinoderms formed an important portion of the zoobenthos in the NW region and also close to the Kara Gate strait, while a similar distribution pattern was observed in crustaceans. In the southern Pechora Sea, where the biomass is low, bryozoan populations play an important role in benthic communities.

\section{Abundance and biomass}

Total macrofauna abundance varied greatly in the study area (384 to 6732 ind. $\mathrm{m}^{-2}$ ). The highest densities were recorded in the SE area at the depth interval of 25 to $50 \mathrm{~m}$, on sand and partly clayey sediments (Appendix 1, available at www.int-res.com/journals/ suppl/denisenko-appendix.pdf). Areas with a relatively low number of specimens were found close to the Pechora and Khaypudir Bays $(<20 \mathrm{~m})$, on erosion bottoms with sandy and partly sandy-mud sediments, and in areas characterised by high-velocity currents. From the Novaya Zemlya towards the Pomorskiy Strait, the zoobenthos densities were nearly always dominated by polychaetes, with the dominant species having densities between $\sim 200$ and 500 ind. $\mathrm{m}^{-2}$. Within bivalve species, the highest densities were recorded for

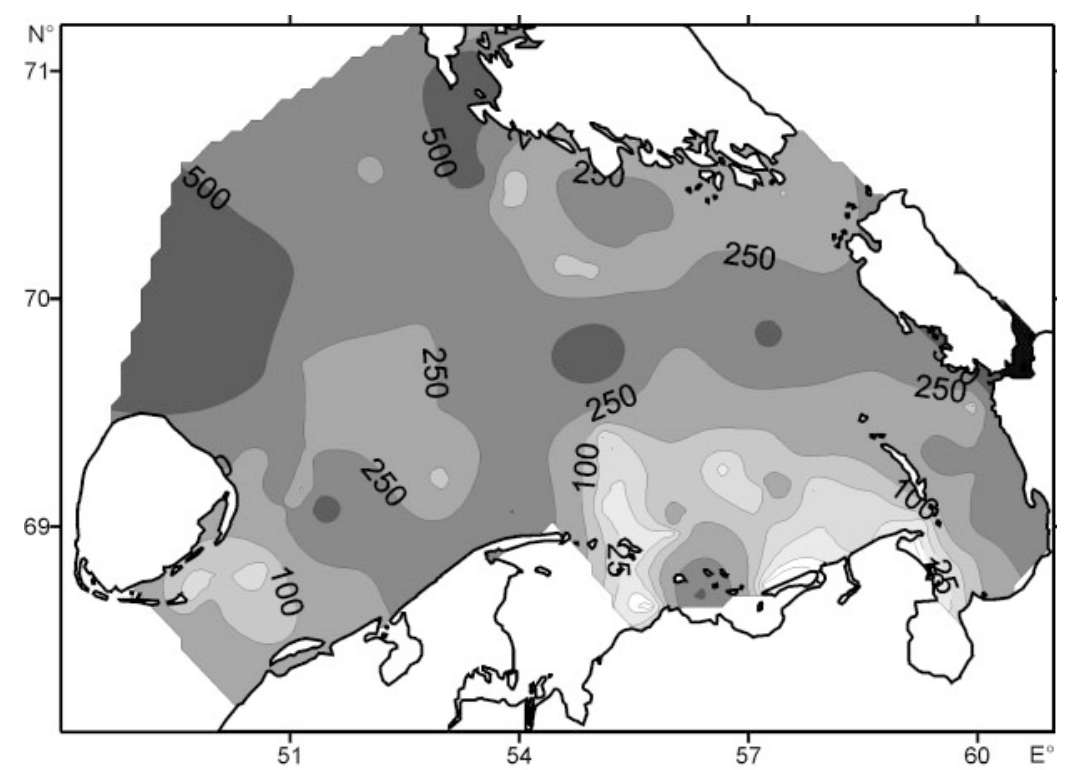

Fig. 4. Total biomass distribution ( $\mathrm{g}$ wet $\mathrm{wt} \mathrm{m}^{-2}$ ) of macrozoobenthos in the Pechora Sea 


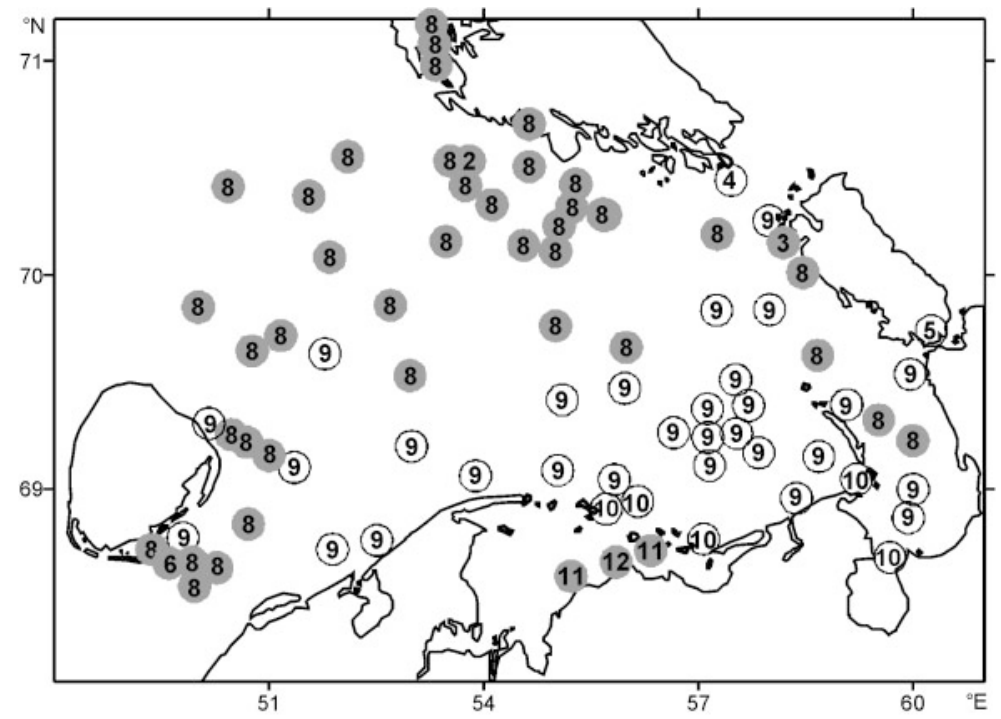

Fig. 5. Distribution of macrozoobenthic communities in the Pechora Sea. Community types are numbered according to Table 2. (O) communities with predominance of deposit feeders; $(O)$ predominance of suspension feeders. Symbols for Type 1 (opposite Pechora Bay), Type 7 (in western part of open sea area) and Type 13 (in Khaypudir Bay) are hidden behind other stations

\section{Community structure and feeding type}

Using a clusterisation dendrogram, 13 benthic community types (marked as Types 1 to 13) were distinguished (Fig. 5, Table 2). Types 8 and 9 are very large and occupy mostly offshore areas, with the former occupying the deeper areas and the latter the shallower parts. Types 6, 10 and 11 occur in restricted areas characterised by distinct hydrographic and hydrodynamic conditions. The remaining 8 community types occur only at single stations with no apparent relation to the adjacent types, being encountered in different parts of the Pechora Sea on variable bottom substrates.

The classification tree method confirms the community type determinations and shows the possible correlations between the community types and selected environmental factors (Fig. 6). The method showed that only 2 factors, depth and TOC, could explain the

Table 2. Benthic community types in the Pechora Sea, with the 10 most important species in each type ranked according to the Species Validity Index (SVI), calculated using abundance, biomass and frequency of occurrence values (see text). 'Frequency of occurrence' is the proportion of stations where the species was found in regard to all stations assigned to a specific community type. Samples were assigned to different communities using average similarity level of 8.93. g. sp. = genus species

\begin{tabular}{|c|c|c|c|c|c|c|c|c|c|}
\hline $\begin{array}{l}\text { Community type } \\
\text { Dominant species }\end{array}$ & $\begin{array}{l}\text { Abund. } \\
\text { ind. } \mathrm{m}^{-2} \text { ) }\end{array}$ & $\begin{array}{l}\text { Biom. } \\
\left(\mathrm{g} \mathrm{m}^{-2}\right)\end{array}$ & $\begin{array}{c}\text { Freq. of } \\
\text { occur- } \\
\text { rence }\end{array}$ & $\begin{array}{c}\text { SVI\%/ } \\
\text { absolute } \\
\text { value }\end{array}$ & $\begin{array}{l}\text { Community type } \\
\text { Dominant species }\end{array}$ & $\begin{array}{l}\text { Abund. } \\
\text { (ind. } \mathrm{m}^{-2} \text { ) }\end{array}$ & $\begin{array}{l}\text { Biom. } \\
\left(\mathrm{g} \mathrm{m}^{-2}\right)\end{array}$ & $\begin{array}{c}\text { Freq. o } \\
\text { occur- } \\
\text { rence }\end{array}$ & $\begin{array}{c}\text { SVI\%/ } \\
\text { absolute } \\
\text { value }\end{array}$ \\
\hline \multicolumn{5}{|c|}{ Type 1: Stegophiura nodosa community } & \multicolumn{5}{|c|}{ Type 3: Strongylocentrotus pallidus community } \\
\hline \multicolumn{5}{|c|}{ Stations: $1 \quad$ Samples: 1 Species: 16} & \multicolumn{5}{|c|}{ Stations: 1 Samples: $2 \quad$ Species: 112} \\
\hline Stegophiura nodosa & 40 & 0.140 & 1.00 & $36.0 / 0.57$ & Strongylocentrotus & 12 & 98.360 & 1.00 & $41.0 / 57.72$ \\
\hline Cylichna alba & 8 & 0.052 & 1.00 & $11.0 / 0.18$ & pallidus & & & & \\
\hline Pseudopolynices nanus & us 4 & 0.057 & 1.00 & $10.0 / 0.16$ & Myriapora subgracilis & 212 & 11.720 & 1.00 & $16.0 / 23.91$ \\
\hline Priscillina armata & 8 & 0.040 & 1.00 & $9.0 / 0.15$ & Cellepora incrassata & 36 & 11.100 & 1.00 & $10.0 / 14.86$ \\
\hline Astartidae sp. & 32 & 0.016 & 1.00 & $7.0 / 0.11$ & Macoma calcarea & 60 & 17.360 & 0.50 & $9.0 / 11.83$ \\
\hline Ostracoda g.sp. & 228 & 0.008 & 1.00 & $6.0 / 0.10$ & Byblis minuticornis & 400 & 6.436 & 0.50 & $8.0 / 9.03$ \\
\hline Lembos arcticus & 40 & 0.012 & 1.00 & $5.0 / 0.09$ & Ophiura robusta & 88 & 6.240 & 0.50 & $5.0 / 6.05$ \\
\hline Montacuta maltzani & 20 & 0.012 & 1.00 & $4.0 / 0.07$ & Admete viridula & 8 & 6.800 & 0.50 & $3.0 / 3.54$ \\
\hline Macoma calcarea & 4 & 0.007 & 1.00 & $2.0 / 0.03$ & Nephtys ciliata & 4 & 7.288 & 0.50 & $3.0 / 3.14$ \\
\hline \multirow[t]{2}{*}{ Naticidae g.sp. } & 4 & 0.004 & 1.00 & $1.0 / 0.02$ & Rhodine gracilior & 86 & 0.400 & 1.00 & $1.0 / 1.53$ \\
\hline & & & & & Chone duneri & 32 & 0.928 & 0.50 & $0.9 / 1.12$ \\
\hline \multicolumn{5}{|c|}{ Type 2: Ctenodiscus crispatus community } & \multicolumn{5}{|c|}{ Type 4: Hiatella arctica-Chone duneri community } \\
\hline \multicolumn{5}{|c|}{ Stations: 1 Samples: 3 Species: 38} & \multicolumn{5}{|c|}{ Stations: 1 Samples: 1 Species: 100} \\
\hline Ctenodiscus crispatus & 46 & 99.260 & 0.67 & $51.1 / 54.58$ & Hiatella arctica & 84 & 29.416 & 1.00 & $25.0 / 38.24$ \\
\hline Ophiocten sericeum & 60 & 11.040 & 0.67 & $10.7 / 11.24$ & Chone duneri & 520 & 10.940 & 1.00 & $19.0 / 28.72$ \\
\hline Lumbrineris sp. & 420 & 3.000 & 0.67 & $5.7 / 6.08$ & Mya truncata & 92 & 7.434 & 1.00 & $9.0 / 13.94$ \\
\hline Scalibregma inflatum & 420 & 2.380 & 0.67 & $5.4 / 5.73$ & Elliptica elliptica & 36 & 8.676 & 1.00 & $8.0 / 12.38$ \\
\hline Owenia fusiformis & 160 & 5.600 & 0.33 & $4.1 / 4.32$ & Laphania boecki & 364 & 3.264 & 1.00 & $7.0 / 10.61$ \\
\hline Golfingia margaritacea & a 12 & 8.320 & 0.33 & $2.9 / 3.04$ & Glycera capitata & 100 & 3.316 & 1.00 & $5.0 / 7.77$ \\
\hline Eupyrgus scaber & 40 & 4.480 & 0.33 & $2.4 / 2.58$ & Ophiacantha & 12 & 4.040 & 1.00 & $3.0 / 5.30$ \\
\hline Terebellides stroemi & 140 & 1.120 & 0.67 & $2.3 / 2.44$ & bidentata & & & & \\
\hline Diastylis goodsiri & 40 & 1.260 & 0.67 & $1.6 / 1.89$ & Mya arenaria & 12 & 3.320 & 1.00 & $2.5 / 4.58$ \\
\hline \multirow[t]{2}{*}{ Haploops tubicola } & 160 & 1.840 & 0.33 & $1.6 / 1.87$ & Ampharete goeesi & 28 & 2.124 & 1.00 & $2.0 / 4.05$ \\
\hline & & & & & Polychaeta sp. & 16 & 3.484 & 1.00 & $3.0 / 5.10$ \\
\hline
\end{tabular}


Table 2 (continued)

\begin{tabular}{|c|c|c|c|c|c|c|c|c|c|}
\hline $\begin{array}{lc}\text { Community type } & \mathrm{Ab} \\
\text { Dominant species } & \text { (ind }\end{array}$ & $\begin{array}{l}\text { Abund. } \\
\text { ad. } \mathrm{m}^{-2} \text { ) }\end{array}$ & $\begin{array}{l}\text { Biom. } \\
\left(\mathrm{g} \mathrm{m}^{-2}\right)\end{array}$ & $\begin{array}{l}\text { Freq. of } \\
\text { occur- } \\
\text { rence }\end{array}$ & $\begin{array}{l}\text { SVI\%/ } \\
\text { absolute } \\
\text { value }\end{array}$ & $\begin{array}{l}\text { Community type } \\
\text { Dominant species }\end{array}$ & $\begin{array}{l}\text { Abund. } \\
\text { (ind. } \mathrm{m}^{-2}\end{array}$ & $\begin{array}{l}\text { Biom. } \\
\left(\mathrm{g} \mathrm{m}^{-2}\right)\end{array}$ & $\begin{array}{c}\text { Freq. of } \\
\text { occur- } \\
\text { rence }\end{array}$ & $\begin{array}{l}\text { SVI\%/ } \\
\text { absolute } \\
\text { value }\end{array}$ \\
\hline \multicolumn{5}{|c|}{ Type 5: Mytilus edulis community } & \multicolumn{5}{|c|}{ Type 9: Serripes groenlandicus community } \\
\hline \multicolumn{5}{|c|}{ Stations: 1 Samples: 1 Species: 19} & \multicolumn{5}{|c|}{ Stations: 29 Samples: $86 \quad$ Species: 399} \\
\hline Mytilus edulis & 64 & 727.200 & 1.00 & $49.0 / 396.08$ & Serripes groenlandicus & 12 & 76.256 & 0.65 & $27.0 / 26.66$ \\
\hline Chirona hammeri & 160 & 184.000 & 1.00 & $22.0 / 177.68$ & Astarte montagui & 107 & 11.323 & 0.84 & $15.0 / 14.03$ \\
\hline Tridonta borealis & 32 & 246.840 & 1.00 & $18.0 / 148.11$ & Macoma calcarea & 43 & 8.166 & 0.72 & $6.0 / 6.97$ \\
\hline Urticina felina & 28 & 32.360 & 1.00 & $4.0 / 31.21$ & Stegophiura nodosa & 133 & 4.033 & 0.72 & $6.0 / 6.76$ \\
\hline Astarte montagui & 16 & 24.800 & 1.00 & $3.0 / 22.23$ & Pelonaia corrugata & 63 & 21.895 & 0.21 & $5.7 / 5.76$ \\
\hline Astarte crenata & 4 & 26.240 & 1.00 & $2.0 / 16.40$ & Praxillella praetermissa & sa 55 & 6.353 & 0.59 & $5.0 / 5.32$ \\
\hline Hiatella arctica & 16 & 7.720 & 1.00 & $1.0 / 9.26$ & Ciliatocardium ciliatum & $m 7$ & 30.658 & 0.17 & $3.0 / 3.44$ \\
\hline Elliptica elliptica & 8 & 7.532 & 1.00 & $1.0 / 7.65$ & Scoloplos armiger & 83 & 1.111 & 0.90 & $2.5 / 2.76$ \\
\hline Buccinum sp. & 4 & 5.520 & 1.00 & $0.5 / 5.09$ & Owenia fusiformis & 145 & 1.919 & 0.65 & $2.5 / 2.69$ \\
\hline Stomphia coccinea & 12 & 3.560 & 1.00 & $0.5 / 4.82$ & Travisia forbesii & 12 & 7.096 & 0.49 & $2.5 / 2.64$ \\
\hline \multicolumn{5}{|c|}{ Type 6: Pectinaria hyperborea-Lumbrineris fragilis community } & \multicolumn{5}{|c|}{ Type 10: Ophelia limacina community } \\
\hline \multicolumn{5}{|c|}{ Stations: 2 Samples: 4 Species: 88} & \multicolumn{5}{|c|}{ Stations: 8 Samples: $27 \quad$ Species: 120} \\
\hline Pectinaria hyperborea & 262 & 8.040 & 0.50 & $17.0 / 9.02$ & Ophelia limacina & 127 & 3.831 & 0.70 & $20.0 / 6.22$ \\
\hline Lumbrineris fragilis & 47 & 13.560 & 0.50 & $16.0 / 8.11$ & Edwardsiidae sp. & 40 & 10.621 & 0.30 & $14.0 / 4.24$ \\
\hline Maldane sarsi & 75 & 2.510 & 1.00 & $9.0 / 5.84$ & Travisia forbesii & 21 & 1.915 & 0.81 & $7.0 / 2.65$ \\
\hline Nuculoma bellotii & 59 & 2.153 & 1.00 & $9.0 / 4.87$ & Eucratea loricata & 57 & 7.103 & 0.22 & $7.0 / 2.49$ \\
\hline Scoloplos armiger & 148 & 2.180 & 0.50 & $8.0 / 3.13$ & Scoloplos armiger & 45 & 0.884 & 1.00 & $6.0 / 2.14$ \\
\hline Macoma sp. & 50 & 6.566 & 0.25 & $7.0 / 2.73$ & Nephtys longosetosa & 22 & 1.648 & 0.74 & $6.0 / 2.08$ \\
\hline Artacama proboscidea & a 10 & 4.020 & 0.50 & $6.0 / 2.49$ & Astarte montagui & 23 & 1.423 & 0.44 & $3.0 / 1.13$ \\
\hline Rhodine gracilior & 130 & 3.800 & 0.25 & $6.0 / 2.30$ & Foraminifera g.sp. & 144 & 0.650 & 0.30 & $2.4 / 0.74$ \\
\hline Stegophiura nodosa & 68 & 3.800 & 0.25 & $5.0 / 1.95$ & Stegophiura nodosa & 100 & 0.564 & 0.26 & $1.7 / 0.53$ \\
\hline Saduria sabini & 16 & 5.800 & 0.25 & $5.0 / 1.87$ & Cryptonatica affinis & 18 & 3.141 & 0.15 & $1.5 / 0.49$ \\
\hline \multicolumn{5}{|c|}{ Type 7: Mya truncata community } & \multicolumn{5}{|c|}{ Type 11: Macoma balthica community } \\
\hline \multicolumn{5}{|c|}{ Stations: 1 Samples: 1 Species: 91} & \multicolumn{5}{|c|}{ Stations: 2 Samples: $14 \quad$ Species: 28} \\
\hline Mya truncata & 48 & 437.120 & 1.00 & $39.0 / 251.63$ & Macoma balthica & 654 & 267.837 & 0.93 & $89.0 / 307.51$ \\
\hline Trichotropis borealis & 48 & 116.400 & 1.00 & $14.0 / 93.28$ & Cyrtodaria kurriana & 90 & 157.540 & 0.07 & $3.0 / 9.78$ \\
\hline Golfingia margaritacea & 16 & 78.560 & 1.00 & $9.0 / 52.77$ & Portlandia & 93 & 9.024 & 0.43 & $2.0 / 6.86$ \\
\hline Buccinum polare & 16 & 62.400 & 1.00 & $7.0 / 44.40$ & aestuariorum & & & & \\
\hline Macoma calcarea & 192 & 25.696 & 1.00 & $7.0 / 42.48$ & Pontoporeia femorata & 622 & 2.105 & 0.71 & $2.0 / 6.19$ \\
\hline Chaetozone setosa & 1344 & 6.152 & 1.00 & $3.0 / 23.65$ & Halicryptus spinulosus & $S \quad 70$ & 3.574 & 0.93 & $1.5 / 5.60$ \\
\hline Lumbrineris fragilis & 192 & 8.400 & 1.00 & $2.5 / 18.37$ & Amauropsis islandica & 10 & 8.520 & 0.14 & $0.5 / 1.08$ \\
\hline Astarte montagui & 24 & 12.400 & 1.00 & $2.0 / 14.63$ & Nemertini g.sp. & 18 & 0.564 & 0.79 & $0.5 / 1.01$ \\
\hline Maldane sarsi & 112 & 4.976 & 1.00 & $1.0 / 10.84$ & Spionidae g.sp. & 71 & 0.780 & 0.43 & $0.5 / 0.96$ \\
\hline \multirow[t]{2}{*}{ Lepeta coeca } & 320 & 3.008 & 1.00 & $1.0 / 9.66$ & Diastylis sulcata & 161 & 0.302 & 0.64 & $0.5 / 0.88$ \\
\hline & & & & & Naticidae g.sp. & 10 & 12.400 & 0.07 & $0.5 / 0.84$ \\
\hline \multicolumn{5}{|c|}{ Type 8: Spiochaetopterus typicus-Tridonta borealis community } & \multicolumn{5}{|c|}{ Type 12: Halicryptus spinulosus community } \\
\hline \multirow{3}{*}{\multicolumn{2}{|c|}{$\begin{array}{l}\text { Spiochaetopterus } \\
\text { typicus }\end{array}$}} & Species: 55 & & & Stations: 1 Samples: 3 & 3 Spec & cies: 4 & & \\
\hline & & 59.979 & s0.60 & $21.0 / 43.34$ & Halicryptus spinulosus & 30 & 2.167 & 1.00 & $57.0 / 4.10$ \\
\hline & & & & & Nemertini g.sp. & 25 & 0.850 & 0.67 & 18.0/1.32 \\
\hline Tridonta borealis & 24 & 120.127 & 0.49 & 19.0/37.92 & Marenzelleria arctia & 15 & 0.530 & 0.67 & $25.0 / 1.78$ \\
\hline Ciliatocardium ciliatum & $m 22$ & 62.026 & 0.58 & $11.0 / 24.18$ & Cirratulidae g.sp. & 10 & 0.020 & 0.33 & $0.1 / 0.03$ \\
\hline Maldane sarsi & 208 & 15.972 & 0.90 & $11.0 / 23.26$ & & & & & \\
\hline Macoma calcarea & 77 & 29.393 & 0.53 & $8.0 / 16.23$ & \multicolumn{5}{|c|}{ Type 13: Diastylis sulcata- Eucratea loricata community } \\
\hline Golfingia margaritacea & 10 & 41.245 & 0.30 & $0.4 / 7.77$ & \multicolumn{5}{|c|}{ Stations: 1 Samples: 1 Species: 6} \\
\hline Astarte montagui & 32 & 10.417 & 0.53 & $0.4 / 6.41$ & Diastylis sulca & & 0.470 & 1.00 & $40.0 / 1.51$ \\
\hline Yoldia hyperborea & 39 & 10.396 & 0.44 & $0.3 / 5.70$ & Eucratea loricata & $\begin{array}{l}50 \\
40\end{array}$ & 0.480 & 1.00 & $39.0 / 1.45$ \\
\hline Ctenodiscus crispatus & 13 & 26.849 & 0.22 & $0.3 / 4.64$ & $\begin{array}{l}\text { Eucratea loricata } \\
\text { Sertularia cupressoides }\end{array}$ & $\begin{array}{c}40 \\
\text { es }\end{array}$ & 0.100 & 1.00 & $7.0 / 0.27$ \\
\hline Serripes groenlandicus & IS 14 & 32.800 & 0.14 & $0.2 / 3.39$ & Onisimus plautus & 10 & 0.060 & $\begin{array}{l}1.00 \\
1.00\end{array}$ & $6.0 / 0.22$ \\
\hline & & & & & Macoma sp. & 10 & 0.040 & 1.00 & $5.0 / 0.16$ \\
\hline & & & & & Sertularia albimaris & 5 & 0.040 & 1.00 & $4.0 / 0.13$ \\
\hline
\end{tabular}


spatial distribution patterns of the community types. Other environmental parameters included in the analysis, such as average summer temperature of the water column, surface and near-bottom salinity (in summer), near-bottom oxygen content and sediment type, were ignored by the method due to low explanatory power.

The largest community type (8), which was positively correlated with depth and TOC, mostly occurs at depths $>35 \mathrm{~m}$ and with TOC $>0.79 \%$. The next 2 large communities (Types 9 and 10), negatively correlated with depth, occur at depths $<35 \mathrm{~m}$. Type 9 occupies the depth range between 13 and $35 \mathrm{~m}$ and sediment TOC $<0.79 \%$, while Type 10 resides at depths $<13 \mathrm{~m}$ and TOC $<0.41 \%$. The deposit-feeder (DF) mode is predominant in 9 community types (Table 3). Of these, only 2 small communities (Types 2 and 6) show predomination or equal portions of subsurface depositfeeders (SSDF) over surface deposit-feeders (SDF). A considerable portion of the shallow-water $(<10 \mathrm{~m})$ communities close to the mouths of the Pechora Bay (Types 11 and 12) and Khaypudir Bay (Type 13) consists of the SDF type. The widespread Type 8 offshore community, as well as the Type 3 in the Kara Gate strait, also belong to the SDF type, although they include a large portion of suspension feeders (SF; 40 and $29 \%$ respectively). The Type 8 community covers more than half of the Pechora Sea area and exists on variable substrates.

Type 10, the largest of the shallow-water DF communities, is found almost exclusively in the offshore sandy-bottom areas outside the Pechora Bay. It consists of small-sized animals, has a low biomass and shows low relative-production values. It also contains a large proportion of predators and may therefore be regarded as atypical for the investigation area.

The 4 remaining community types belong to the SF type, with the most extensive being Type 9, which occupies the $<20 \mathrm{~m}$ sandy bottoms of the southern offshore area. Type 7 (inhabiting the deeper western part) and Types 4 and 5 (in the coastal environments of the Kara Gate and Yugorskiy Shar straits) are found in areas characterised by mixed sediments with a predomination of pebble and gravel.

\section{Biogeography}

The Pechora Sea macrozoobenthic fauna is dominated by boreal-Arctic species, which comprise $\sim 70 \%$ of all specimens identified to the species level (Table 4). A total of $15 \%$ of the species are Arctic and $11 \%$ have a boreal origin, while the small remainder consists of cosmopolitan and subtropic-boreal-Arctic species. The relative proportions of Arctic and boreal species, regarded here as indicator species, demonstrate the predomination of Arctic species in the Prinovozemelskiy Trough and east of the Kolguyev Island (where no boreal species were found) and also at the shallowest stations inside the Khaypudir Bays (Fig. 7). In the southern part of the Pechora Sea, north of the mainland, southeast from the Kolguyev Island and in the Yugorskiy Shar strait, boreal species predominate over those with Arctic origins.

\section{DISCUSSION}

\section{Diversity and community structure}

The macrobenthic fauna in the Pechora Sea is more diverse than many other Arctic areas (e.g. Chukchi Sea: Feder et al. 1994; Canadian shelf areas: Thomson 1982, Stewart et al. 1985). Although the total number of taxa (712) reported here at 87 stations include 505 species, they represent only $\sim 35 \%$ of that observed in the whole Barents Sea area (Zenkevich 1963, Sirenko 1998), the Pechora Sea can be regarded as considerably species-rich. The high number of taxa in this study compared with other reports from this area (Zenkevich 1927, Dahle et al. 1998) may be explained by the much greater number of stations studied and by the high accuracy of species determination. The high species richness observed in the area is probably a reflection of the influence of different water masses (the Arctic, Atlantic and coastal run-off water) and bottom topography.

The present study, as well as the results by Dahle et al. (1998), indicates great variability in the spatial distribution of zoobenthos in the area, mostly agreeing with the early data presented by Brotskaya \& Zenkevich (1939). The high diversity $\left(H^{\prime}=2\right.$ to 5$)$, based on the present material and that by Dahle et al. (1998), suggests stability of the local benthic communities in most parts of the Pechora Sea. The values are also similar to those recorded in some other Arctic sea areas (White Sea: Babkov \& Golikov 1985; Canadian shelf: Stewart et al. 1985; Greenland fjords: Sejr et al. 2000; Chukchi and Bering Seas: Grebmeier et al. 1989).

The determination of benthic communities or associations has traditionally been based either on abundance or biomass. Following the views of Winberg (1971), Wittaker (1975) and Alimov (1989) we consider that the significance of a species in a community is estimated in an improved way by taking into account their production capacity, which in this work was achieved by combining the abundance and biomass of the species. Such a method for the estimation of zoobenthic production has been shown useful by Brey (1990), and was found suitable also for material collected from 


\section{COMMUNITIES}

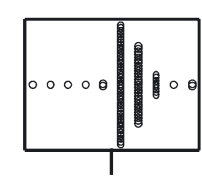

Impurity $=3.24$

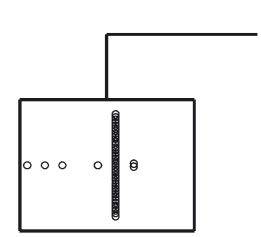

Community 8 Impurity $=0.125$ $\mathrm{n}=4$
Fig. 6. Classification tree analysis of the Pechora Sea macrozoobenthic communities, using selected environmental parameters as factors (see section 'Community structure and feeding type' for explanations). Every box containing data is a 'density display' of the community types on a common scale (the same limits and the same direction). When the box occurs on the left side from the split, the relation between factor and community type is positive. Number of spots in vertical rows (lines) reflects the number of stations used for community analysis, the number of vertical lines in the horizontal rows of each box reflects the number of communities related with the examined factors the Russian Arctic (Denisenko \& Denisenko 1990, Kucheruk 1995, Kucheruk et al. 1998). The advantage of the 'production method' is that it evens out differences caused by (1) numerous small-bodied organisms present in a single sample and (2) a single large individual of 1 species present in a single sample. Using production estimates makes statistical grouping of samples collected throughout the year feasible, including periods of mass larval settlement, without causing major errors in the dominance relationships within a community. Still, animals with a heavy exoskeleton may create a problem: if the skeleton is included in the biomass, the proportion of these species in the community will be overestimated. On the other hand, the for-

Table 3. Main feeding modes of different community types (see Table 2), based on analysis of 15 most important species in each community as their proportion (\%) of total biomass of the community. SF = suspension feeder, DF = deposit feeder, SDF $=$ surface deposit feeder, SSDF = subsurface deposit feeder, $\mathrm{PRED}=$ predator

\begin{tabular}{|c|c|c|c|c|}
\hline $\begin{array}{l}\text { Main feeding } \\
\text { mode }\end{array}$ & Community type & $\mathrm{SF}$ & $\mathrm{DF}$ (SDF / SSDF) & PRED \\
\hline \multirow[t]{9}{*}{$\mathrm{SDF}$} & 1: Stegophiura nodosa & 20.0 & $56.1(56.1 /-)$ & 23.9 \\
\hline & 2: Ctenodiscus crispatus & - & $98.9(42.3 / 57.6)$ & 0.1 \\
\hline & 3: Strongylocentrotus pallidus & 29.0 & $66.2(64.4 / 1.8)$ & 4.8 \\
\hline & 6: Pectinaria hyperborea-Lumbrineris fragilis & 2.6 & $80.4(40.5$ / 39.9) & 17.0 \\
\hline & 8: Spiochaetopterus typicus-Tridonta borealis & 40.8 & $59.8(39.9$ / 19.2) & 0.1 \\
\hline & 10: Ophelia limacina & 17.4 & $54.4(51.4 / 3.0)$ & 28.2 \\
\hline & 11: Macoma balthica & 2.9 & $96.2(96.2 /-)$ & 0.9 \\
\hline & 12: Halicryptus spinulosus & & $78.8(78.8 /-)$ & 21.2 \\
\hline & 13: Diastylis sulcata-Eucratea loricata & 38.8 & $44.7(44.7 /-)$ & 16.5 \\
\hline \multirow[t]{4}{*}{ SF } & 4: Hiatella arctica-Chone duneri & 53.5 & $46.5(46.5 /-)$ & - \\
\hline & 5: Mytilus edulis & 94.5 & $0.3(0.3 /-)$ & 5.2 \\
\hline & 7: Mya truncata & 46.7 & $24.4(12.3 / 12.1)$ & 28.9 \\
\hline & 9: Serripes groenlandicus & 60.2 & $39.8(35.3 / 4.5)$ & - \\
\hline
\end{tabular}


Table 4. Biogeographic grouping of macrozoobenthic species in the Pechora Sea. Total number or share (\%) of species within each main biogeographic group are given in bold

\begin{tabular}{|lcr|}
\hline $\begin{array}{l}\text { Biogeographic characteristic } \\
\text { of species }\end{array}$ & $\begin{array}{l}\text { No. of } \\
\text { species }\end{array}$ & \\
\hline Boreal & $\mathbf{6 0}$ & $\mathbf{1 1 . 2}$ \\
Amphiboreal & 19 & 3.5 \\
Widespread boreal & 16 & 3.0 \\
Atlantic boreal & 16 & 3.0 \\
Atlantic high-boreal & 9 & 1.7 \\
Arctic & $\mathbf{8 0}$ & $\mathbf{1 4 . 9}$ \\
Circumpolar Arctic & 64 & 11.9 \\
Western Arctic & 9 & 1.7 \\
Eastern Arctic & 7 & 1.3 \\
Boreal-Arctic & $\mathbf{3 7 1}$ & $\mathbf{6 8 . 9}$ \\
Widespread and circumpolar & 274 & 50.9 \\
Boreal-Arctic & & \\
Atlantic boreal-Arctic & 53 & 9.9 \\
Atlantic high-boreal & 27 & 5.0 \\
Pacific boreal-Arctic & 17 & 3.1 \\
Subtropic-boreal-arctic & $\mathbf{2 3}$ & $\mathbf{4 . 3}$ \\
Cosmopolitan & $\mathbf{4}$ & $\mathbf{0 . 7}$ \\
\hline
\end{tabular}

mation of the exoskeleton also consumes energy, and therefore the use of soft tissues only leads to an underestimation of true production. In the present study the exoskeleton was included in the calculations, which should be kept in mind when interpreting the results. Comparison of community structures, based on production values with the previously published data based on analyses of biomass (Zenkevich 1927, Brotskaya \& Zenkevich 1939, Antipova 1975a) or abundance (Dahle et al. 1998), reveals certain dissimilarities, although the general pattern of biomass or abundance distribution is similar in the different studies. In the present study the importance of large molluscs is less, and the number of communities in the offshore area is smaller, with their boundaries differing markedly in some cases. Furthermore, in all the previous studies (except for Dahle et al. 1998) the area of distribution of each community type was assumed to follow the isolines of bottom topography, taking into account only rough sediment characteristics. All the earlier studies also contained considerably fewer stations. Only in the work by Dahle et al. (1998) was the determination of communities based on valid statistical analyses. Based on sampling in the 1990s, Pogrebov et al. (1997) determined 26 community types in the study area. Although their results are not directly comparable due to methodological discrepancies, both studies illustrate the mosaic character of the near-shore fauna and the greater homogeneity of the fauna in the open-sea areas.

Of the 13 community types identified by using the relative production method, more than half have been described before (Types 1, 3, 4, 6, 8 and 9; see Table 2) from the Barents Sea and from other regions of the Arctic Ocean (Stoker 1981, Thomson 1982, Carey 1991, Petriashov et al. 1999). The earlier-described communities include the 2 most widespread types in the offshore areas, the Spiochaetopterus typicusTridonta borealis community (Type 8) in the deeper parts, and the Serripes groenlandicus community (Type 9) in the shallower areas. In the investigation area the Mytilus edulis and Macoma balthica communities, common in boreal temperate areas of the Atlantic coastal zone (Kröncke 1995, Davoult et al. 1998), were characterised by the occurrence of some Arctic species. The Mytilus edulis community (Type 5) occurred in the Yugorskiy Shar strait, an area with a hard bottom and strong currents. The communities predominated by Macoma balthica (Type 11), Ophelia limacina (Type 10), Diastylis sulcata (Type 13) and Halicryptus spinulosus (Type 12) were found in the shallow coastal abrasion areas of the Khaypudir Bay and outside the Pechora Bay, in areas never investi-

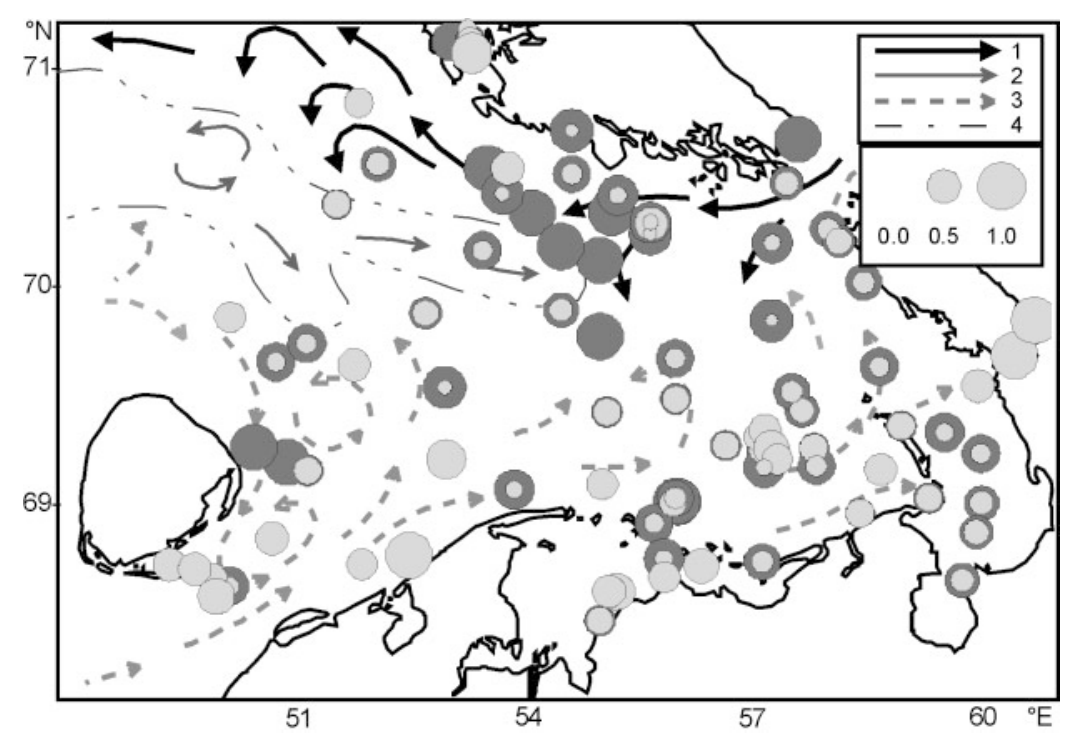

Fig. 7. Relative proportions of macrozoobenthic biogeographic indicator species, i.e. boreal forms in comparison with Arctic species at the sampling stations (see also Table 4). The map also describes the distribution of main water currents (Potanin 1981) in the Pechora Sea: (1) cold Arctic water, (2) transformed Atlantic water, (3) warm water from the White Sea and (4) the boundary of the area influenced by Atlantic waters. Light circles $=$ boreal species, dark circles $=$ Arctic species. Size of light circles reflects relative portion of boreal species at each station: $0.0=$ no boreal species, $1.0=$ only boreal species 
gated before. Both these areas are unstable, with seasonally fluctuating salinity and temperature conditions combined with ice scouring.

Large, mobile species, such as carnivorous echinoderms, gastropods and decapods, which are rarely caught by grab sampling, are typical for the Pechora Sea area. These occasionally occurring species usually cause strong variations in the biomass when present in a sample. However, the population density of, large echinoderms, for example, is in general very low in Arctic seas (Piepenburg \& Schmidt 1997), and this holds true for the Pechora Sea as well (Khodkina 1964).

\section{Effects of abiotic factors and sediment type}

In Arctic areas, a number of crucial environmental factors, such as bottom topography, sediment type and water depth, govern the structure of benthic communities (e.g. Kusnetsov 1970, Thomson 1982, Long \& Lewis 1987, Grebmeier et al. 1989, Feder et al. 1994, Dahle et al. 1998, Sejr et al. 2000). In the Pechora Sea open-sea areas the environmental conditions are typically more stable than in the highly varying coastal areas, which are affected by seasonal variations in ice scouring, freshwater discharge and temperature.

All the environmental factors examined here show significant spatial variation, while TOC and depth were shown to be the most important factors affecting the distribution of the community types. However, it should be noted that temperature is tightly coupled with depth in this region. Sediment structure was not included in the analyses because the data available are too rough to give adequate resolution (see Appendix 1, available at www.int-res.com/journals/suppl/ denisenko-appendix.pdf), but combined with TOC it most likely is of fundamental importance for the benthic communities.

The main sources of sediment organic carbon enrichment in the area are detritus originating from the decaying coastal seaweed and organic particulate material transported by the Pechora River. Recent evidence has also shown that phytoplankton-derived carbon may enrich the seafloor beneath highly productive ice-edge zones (Savinov 1997, Makarevich 1998, FalkPetersen et al. 2000).

Accumulation areas with high concentrations of TOC and muddy bottoms are generally characterised by high macrozoobenthos abundance (cf. Dahle et al. 1998). Very soft accumulation bottoms with high TOC content occur in the Pomorskiy Strait and in the Prinovozemelskiy Trough (Gorshkova 1957, Loring et al. 1995). In these areas a considerable proportion of the local biomass is formed by deposit-feeding polychaetes typically predominating in very soft muddy sedi- ments where heavy-shelled large bivalves (e.g. Tridonta borealis, Astarte montagui) are unable to survive. The same situation is observed in the 6 -station transect eastward of the Kolguyev Island, where a gradual change in zoobenthic community structure is noted as the sediment type and TOC concentration change. In this $50 \mathrm{~m}$ depression, with a very soft bottom and a high TOC concentration, the community is predominated by small polychaetes. Of bivalves, only the smaller and lighter specimens are able to survive in this type of sediment without sinking too deep into the mud.

The richest fauna was found in accumulation areas with mixed sediments. In the northern Pechora Sea, in the vicinity of the Kara Gate strait and the Dolgiy Island, very high abundance and biomass values were observed. Zenkevich (1963) proposed that the deep areas southwest of Novaya Zemlya - characterised by high biomass of Tridonta borealis, for example-are supported by large amounts of detritus originating from the abundant seaweed growths in the coastal area. The effect of organic particulate material from the Pechora River may also extend to this area (Lisitsin 1995). Also, phytoplankton-derived carbon in connection to the ice edge area may be of importance (see above).

The small communities dominated by deposit feeders (such as the echinoderms Ctenodiscus crispatus south of Novaya Zemlya, Stongylocentrotus pallidus at a station near the Kara Gate strait and Stegophiura nodosa in the southern shallow part) reflect the coarser sediment type present in these areas. All these areas are also characterised by a low TOC content of the sediments. The hard sediment, which in the 2 latter regions is caused by strong currents, also supports a rich bryozoan fauna. Regions with a more intense water mixing, lower sediment TOC concentration and a high concentration of organic matter in the water column are occupied by communities predominated by suspension feeders (Table 3), e.g. molluscs and bryozoans. In the southern part of the Pechora Sea, e.g. in the shallow $(<15 \mathrm{~m})$ coastal areas and the Kara Gate and Yugorskiy Shar straits, the high current velocities and wave mixing on the sandy erosion bottoms effectively inhibit sedimentation of organic matter.

In the deep Pechora Sea, the near-bottom salinity and temperature probably have a minor influence on the zoobenthos distribution due to small variability. In contrast, in the shallow, brackish bay-mouth areas, the benthic communities (Types 1, 12 and 13; see Table 2) are physiologically stressed and the low diversity could be coupled to variations in salinity (cf. Remane \& Schlieper 1971). Ice scouring also disturbs the benthos, as shown in other Arctic shallow areas (Gutt et al. 1996, Conlan et al. 1998). Consequently, diversity in 
Table 5. Proportion (\%) of the most dominant species (1 to 5) in each community type, grouped to 3 different categories that describe the community type's susceptibility to changes. ANOVA with post hoc Tukey on arcsine-transformed values shows differences between the groups at $\mathrm{p}>0.05$ significance level, with the letters A to C indicating the significantly differing group(s)

\begin{tabular}{|lllcrrr|}
\hline \multirow{2}{*}{ Group } & \multicolumn{5}{c}{ Dominant species (\% of total \pm SD) } \\
\cline { 2 - 5 } & \multicolumn{1}{c}{1} & $1+2$ & $1+2+3$ & $1+2+3+4$ & $1+2+3+4+5$ & Rest \\
\hline I: Flexible: Types 4, 6, 8, 9, 10 & $22 \pm 4 \mathrm{C}$ & $39 \pm 5 \mathrm{C}$ & $47 \pm 1 \mathrm{C}$ & $55 \pm 6 \mathrm{C}$ & $62 \pm 7 \mathrm{BC}$ & $38 \pm 7 \mathrm{BC}$ \\
II: Intermediate: Types 1, 2,3,7 & $42 \pm 7$ & $55 \pm 6 \mathrm{C}$ & $64 \pm 5 \mathrm{C}$ & $71 \pm 4 \mathrm{C}$ & $78 \pm 5 \mathrm{AC}$ & $23 \pm 5 \mathrm{AC}$ \\
III: Susceptible: Types 5, 11, 12,13 & $59 \pm 21 \mathrm{~A}$ & $81 \pm 9 \mathrm{AB}$ & $92 \pm 6 \mathrm{AB}$ & $95 \pm 4 \mathrm{AB}$ & $98 \pm 2 \mathrm{AB}$ & $2 \pm 2 \mathrm{AB}$ \\
\hline
\end{tabular}

these regions is low in comparison with the main part of the Pechora Sea, which shows typical marine characteristics (Adrov \& Denisenko 1996).

The susceptibility of the local zoobenthic communities to changes in environmental conditions is assessed here by grouping the different community types according to the degree of dominance by the 5 most important species in each community, constituting ca. 60 to $100 \%$ of each community (Table 5). The underlying assumption is that communities showing dominance of only a few species are more vulnerable to environmental change than those with a more diverse structure (e.g. Lawton 1991, Walker 1992). Group I consists of communities in which the proportion of each of the 5 dominant species is approximately equal to the portion of the remaining species altogether. This kind of community may be regarded as 'flexible', with a good 'buffering capacity' towards environmental changes: a decrease of 1 species during adverse environmental conditions does not demolish the whole community structure. In the Pechora Sea, all community types showing this structure belong to the DF communities. The Group II communities are located in areas with sub-optimal, but rather steady, conditions. Because the conditions are relatively stable, the communities show 'intermediate' characteristics between Groups I and III, the latter consisting of communities completely dominated by a single species. The Group III communities may be considered as 'susceptible' to environmental changes: both intrinsic (e.g. population overgrowth, crash and recovery) and extrinsic (e.g. temporary inter-annual changes in food availability, pollution incidents) factors may cause large fluctuations in abundance and biomass of the dominant species, resulting in extreme variability in community structure. In the Group III communities the SF feeding mode is dominating, or at least strongly present.

\section{Biogeography}

The developmental history of the Pechora Sea fauna is still unclear. The influence of Atlantic water is reflected in the presence of a relatively large propor- tion of boreal-Arctic (79 species: 14.9\%) and boreal (25 species: $4.0 \%$ ) forms of Atlantic origin. Boreal species with pelagic larvae can reside in the water column for a considerable time and thus spread over long distances with currents from the western part of the Barents Sea. Some of the species, e.g. Macoma balthica and subtidal Mytilus edulis, occur in local, restricted populations in the southern part of the Barents Sea and may be regarded as relict species.

In the northern and NE parts of the Pechora Sea, where temperature remains $<1^{\circ} \mathrm{C}$, boreal species are missing. In the shallow southern and SE areas, in the Pechora Bay and the Yugorskiy Shar strait, warm (5 to $6^{\circ} \mathrm{C}$ ) coastal water masses predominate and boreal species outnumber the Arctic forms. However, as is typical for Arctic estuaries that are ice-covered during the winter, mobile species capable of migrating between habitats predominate in the shallowest parts of these bays (Denisenko et al. 1999).

The NE Pechora Sea is greatly influenced by the Arctic water intruding through the Kara Gate strait and moving along the coast of Novaya Zemlya to the northern part of the Barents Sea, and also by the cooling Barents Sea water of Atlantic origin (see Fig. 7.) Here, the near-bottom temperature is very low, sometimes $<0^{\circ} \mathrm{C}$ during the whole year. In these areas, as well as in the Prinovozemelskiy Trough, Arctic species are in general more abundant than boreal species. All these species have a wide distribution in the Arctic and none of them is endemic. The occurrence of pacific boreal-Arctic species indicates that a connection between the Pechora Sea and the eastern Arctic seas exists. However, the number of species with Pacific origin is small.

The Atlantic Ocean has a strong influence on the species composition of the Pechora Sea. The predominance of widespread boreal-Arctic species, the low number of high boreal-Arctic forms and the absence of endemic forms with Arctic origin indicate that this part of the Barents Sea is a transitional zone between the boreal Atlantic and Arctic biogeographic regions (cf. Antipova et al. 1989), not a typical Arctic region as described by Filatova (1957) and Antipova (1975b). Thus, one might expect a faunal response on climate 
fluctuations, such as an increase/decrease in the proportion of Atlantic species (boreal and boreal-Arctic) during long-term warming/cooling periods. Interannual fluctuations in the heat capacity of the water masses penetrating the Barents Sea and the Pechora Sea have been observed (Adrov \& Denisenko 1996), while also faunal changes related to climate change in this area have been reported, e.g. in molluscs (Galkin 1964, 1998). Climate fluctuations may thus influence the quantitative and qualitative characteristics of the zoobenthos of the Pechora Sea.

Acknowledgements. The authors are grateful to the director of MMBI, Professor Gennady Matishov, for support in the organisation of the expeditions. Benthologists of the MMBI are thanked for species identification: Ms. Ninel Panteleeva (hydroids), Ms. Elena Frolova (polychaetes), Dr. Elena Luppova (crustaceans) and Dr. Natalia Anisimova (echinoderms). Mr. Henrik Sandler (FIMR) is thanked for sampling and preliminary data evaluation. Dr. Pavel Lubin (MMBI) is acknowledged for the data from the Khaypudir Bay. Professor Markku Viitasalo (FIMR) is thanked for comments on the final manuscript.

\section{LITERATURE CITED}

Adrov NM, Denisenko GS (1996) Oceanographic characteristics of the Pechora Sea. In: Matishov GG, Tarasov GA, Denisenko SG, Denisov VV, Galaktionov KV (eds) Biogeocenoses of glacial shelf of the western Arctic seas. Kola Centre RAN, Apatity, p 166-179 (in Russian)

Alimov AF (1989) Introduction into productive hydrobiology. Hydrometizdat, Leningrad (in Russian)

Anisimova NA (1989) Distribution patterns of echinoderms in the Eurasian sector of the Arctic Ocean. In: Herman Y (ed) The Arctic seas: climatology, oceanography, geology, and biology. Van Nostrand Reinhold, New York, p 281-302

Antipova TV (1973) Distribution and abundance of zoobenthos in the southeastern part of the Barents Sea in 1970. Trans Polar Res Inst Mar Fish Oceanogr (PINRO), Murmansk 33:24-33 (in Russian)

Antipova TV (1975a) Distribution of benthos biomass in the Barents Sea. Trans Polar Res Inst Mar Fish Oceanogr (PINRO), Murmansk 35:121-124 (in Russian)

Antipova TV (1975b) Preliminary data on species composition and quantitative distribution of bivalves in the Barents Sea. Okeanologia 15:330-332 (in Russian)

Antipova TV, Denisenko NV, Semenov VN (1989) Distribution of benthic species and problems of biogeographycal zonation of the northern seas. In: Scarlato OA, Matishov GG (eds) Life and environment of the Polar seas. Nauka, Leningrad, p 146-157

Babkov A, Golikov AN (1985) Hydrobiocomplexes of the White Sea. Zool Inst Acad Sci USSR, Leningrad

Brey T (1990) Estimating productivity of macrobenthic invertebrates from biomass and mean individual weight. Meeresforschung 32:329-343

Brotskaya VA, Zenkevich LA (1939) Quantitative estimation of the bottom fauna of the Barents Sea. Trans All Union Res Inst Mar Fish Oceanogr (VNIRO), Moscow 4:3-150 (in Russian)

Carey AG (1991) Ecology of North American Arctic continen- tal shelf benthos: a review. Cont Shelf Res 11:865-883

Conlan KE, Lenihan NS, Kvitek RG, Oliver JS (1998) Ice scour disturbance to benthic communities in the Canadian High Arctic. Mar Ecol Prog Ser 166:1-16

Czekanowski J (1909) Zur Differential-Diagnose der Neandertalgruppe. Korrespondenzblatt der Deutschen Gesellschaft für Anthropologie 40:44-47

Dahle S, Denisenko S, Denisenko N, Cochrane S (1998) Benthic fauna in the Pechora Sea. Sarsia 83:183-210

Davoult D, Dewarumez JM, Migne A (1998) Long-term changes (1979-1994) in two coastal benthic communities (English Channel): analysis of structural developments. Oceanol Acta 21(4):609-617

Denisenko S (1992) Benthic studies. In: Matishov GG (ed) An international (American-Norwegian-Russian) ecological expedition in the Pechora Sea, Novaya Zemlia, Kolguev, Vaygach and Dolgy Islands. July 1992 (RV Dal'niye Zelentsy). MMBI report, Russian Academy of Science, Apatity, p 21-24 (in Russian)

Denisenko NV, Denisenko SG (1990) Biomass, density of populations and their contribution in productivity of bottom communities. In: Anonymous (ed) Problems of nature preservation in the northern areas. Abstracts of Lectures of All Union Science Conference of Young Scientists and Specialists. Apatity, 29-30 Jan, 1990. USSR Academy of Science, Murmansk, p 53-54 (in Russian)

Denisenko SG, Galkin YI (1996) Molluscs: species composition and distribution. In: Matishov GG, Tarasov GA, Denisenko SG, Denisov VV, Galaktionov KV (eds) Biogeocenoses of glacial shelf of the western Arctic Seas. Part 2. Bottom fauna and its environment (Pechora Sea). Russian Academy of Science, Apatity, p 203-216 (in Russian)

Denisenko S, Sandler H, Denisenko N, Rachor E (1999) Current state in two estuarine bays of the Barents and Kara Seas. J Mar Sci 56:187-193

Ekman S (1953) Zoogeography of the sea. Sidgwick \& Jackson, London

Falk-Petersen S, Haakon H, Budgell WP, Hegseth EN (2000) Physical and ecological processes in the marginal ice zone of the northern Barents Sea during the summer melt period. J Mar Syst 27:131-159

Feder HM, Naidu AS, Jewett SC, Hameedi M, Johnson WR, Whitledge TE (1994) The northeastern Chukchi Sea: benthos-environmental interactions. Mar Ecol Prog Ser 111:171-190

Fedyakov VV, Naumov AD (1989) Marine Bivalvia in the Arctic Ocean. In: Herman Y (Ed) The Arctic seas: climatology, oceanography, geology, and biology. Van Nostrand Reinhold, New York, p 303-319

Filatova Z (1957) A review of the bivalve fauna of the northern seas of the USSR. In: Trans Oceanol Inst 20:3-87

Frolova EA (1996) Faunal composition and quantitative distribution of marine bristle-worms (Polychaeta). In: Matishov GG, Tarasov GA, Denisenko SG, Denisov VV, Galaktionov KV (eds) Biogeocenoses of glacial shelf of the western Arctic Seas. Part 2. Bottom fauna and its environment (Pechora Sea). Kola Centre RAN, Apatity, p 180-190 (in Russian)

Galkin YI (1964) Multiannual changes in the distributions of bivalves in the southern part of the Barents Sea. In: Zelekman E (ed) New investigations of plankton and benthos of the Barents Sea. Nauka, Moscow, Leningrad, p 22-40 (in Russian)

Galkin YI (1998) Long-term changes in the distribution of molluscs in the Barents Sea related to the climate. Ber Polarforsch 287:100-143

Golikov AN (1982) About the principles of the division into 
districts and unification of the terms in the marine biogeography. In: Kusakin OG (ed) Marine biogeography: subject, methods, principles of division into districts. Nauka, Moscow, p 94-99 (in Russian)

Gontar VI, Denisenko NV (1989) Arctic Ocean bryozoans. In: Herman Y (ed) The Arctic seas: climatology, oceanography, geology, and biology. Van Nostrand Reinhold, New York, p 341-372

Gorshkov GP (ed) (1980) The Arctic Ocean, Vol 1. Atlas of oceans. Main Department of Navigation and Oceanography of Ministry of Defence of the USSR, Moscow (in Russian)

Gorshkova TI (1957) Organic matter and carbonate in bottom sediments of the Barents Sea. Trans Polar Res Inst Mar Fish Oceanogr (PINRO) 10:260-280

Gray JS, Clarke KR, Warwick RM, Hobbs G (1990) Detection of initial effects of pollution on marine benthos: an example from the Ekofisk and Eldfisk oilfields, North Sea. Mar Ecol Prog Ser 66:285-299

Grebmeier JM, Feder HM, McRoy CP (1989) Pelagic-benthic coupling in the northern Bering and southern Chukchi Seas. II. Benthic community structure. Mar Ecol Prog Ser 51:253-268

Gurevich VJ (1976) The studies of organic components in the bottom sediments of the Barents and White seas. In: Tokin IB (ed) Biology of the Barents and White Seas. Kola Branch of USSR Acad of Sciences, Apatity, p 30-49 (in Russian)

Gutt J, Starmans A, Dieckmann G (1996) Impact of iceberg scouring on polar benthic habitats. Mar Ecol Prog Ser 137: 311-316

Ilyin GV, Matishov GG (1992) Oceanographic conditions in the Pechora Sea in July. In: Matishov GG (ed) An international American-Norwegian-Russian ecological expedition in the Pechora Sea, Novaya Zemlya, Vaygach, Kolguyev and Dolgiy islands, July, 1992 (RV 'Dalnie Zelentzy'). MMBI report, Russian Academy of Science, Apatity, p 7-11 (in Russian)

Khodkina IV (1964) Echinoderms of the southern part of the Barents Sea (on materials from 1957-59): new investigations of plankton and benthos of the Barents Sea. Nauka, Moscow, Leningrad, p 41-75 (in Russian)

Klenova MV (1960) Geology of the Barents Sea. Acad Sci USSR, Moscow, Leningrad (in Russian)

Kröncke I (1995) Long-term changes in North Sea benthos. Senckenb Marit 26(1-2):73-80

Kucheruk NV (1995) Upwelling and benthos: guild structure of few-species communities. Dokl Ross Akad Nauk 2: 276-279

Kucheruk NV, Mokievskiy VO, Denisov NE (1998) Macrobenthos of the coastal shallow zone in the southwestern part of the Kara Sea. Oceanology 38:86-94

Kuznetsov AP (1970) Patterns of distributions of bottom invertebrates trophic groups in the Barents Sea. Trans Oceanol Inst 88:5-80 (in Russian)

Lawton JH (1991) Are species useful? Oikos 62:3-4

Lisitsin AP (1995) The marginal filter of the ocean. Oceanology 34:671-682

Lisitsin AP, Udintsev GB (1955) A new type of grab. Tr Vses Gidrobiol O-va 6:217-222 (in Russian)

Long B, Lewis JB (1987) Distribution and community structure of benthic fauna of the Gulf of Lawrence described by numerical methods of classification and ordination. Mar Biol 95:93-101

Loring DH, Naes K, Dahle S, Matishov GG, Ilyin G (1995) Arsenic, trace metals, and organic microcontamination in sediments from the Pechora Sea, Russia. Mar Geol 2:153-167
Makarevich PR (1998) The vernal state of the microphytoplankton community in the ice-covered areas of the southeastern Barents and the southwestern Kara Seas. In: Matishov GG, Kusnetsov LL, Djenuk SL, Larionov VV, Kusnetsova TL (eds) Biology and oceanography of the Kara and Barents Seas (along the northern marine route). Kola Centre RAN, Apatity, p 138-149

Milliman JD, Syvitski JPM (1992) Geomorphic/tectonic control of sediment discharge to the oceans: the importance of small mountaneous rivers. J Geol 100:525-544

MMBI (Murmansk Marine Biological Institute) - NODC/NOAA (National Oceanic and Atmospheric Administration) (1998) Climate atlas of the Barents Sea (CD-ROM). International ocean atlas series, V 1, WDC-A for Oceanography. US Department of Commerce, Washington, DC

Nikiforov V, Mescherskaya V (1999) Protected areas across the Russian arctic. WWF Arctic Bull 4:12-14

Pesenko YA (1982) Rules and methods of quantitative analysis in faunistic investigations. Nauka, Moscow

Petriashov VV, Sirenko BI, Golikov AA, Novozhilov AV, Rachor E, Piepenburg D, Schmid MK (1999) Macrobenthos distribution in the Laptev Sea in relation to hydrology. In: Kassens H, Bauch HA, Dmitrenko IA, Eicken H, Hubberten HW, Melles M, Thiede J, Timokhov LA (eds) Land-ocean systems in the Siberian Arctic: dynamics and history. Springer-Verlag, Berlin, Heidelberg, p 169-180

Piepenburg D, Schmidt MK (1997) A photographic survey of the epibenthic megafauna of the Arctic Laptev Sea shelf: distribution, abundance, and estimates of biomass and organic carbon demand. Mar Ecol Prog Ser 147:63-75

Pogrebov VB, Ivanov GI, Nekrasova NN (1997) Macrobenthic communities of the Pechora Sea: the past and the present of the threshold of the Prirazlomnoye oil-field exploration. Mar Poll Bull 35(7-12):287-295

Potanin VA (1981) Geographical aspects of the studies on possible changes in climatic and environmental conditions of the Arctic seas by a partial diversion of northern rivers to the south. Priroda i Khozyaistvo Severa 9:56-60 (in Russian)

Remane A, Schlieper C (1971) (eds) Biology of brackish water. Wiley Interscience, New York

Savinov VM (1997) Photosynthetic pigments and primary production of the phytoplankton community in the coastal Barents Sea. In: Matishov GG (ed) Plankton of the sea of the Western Arctic. Kola Centre RAN, Apatity, p 127-145

Sejr MK, Thomas Jensen K, Rysgaard S (2000) Macrozoobenthic community structure in a high-arctic East Greenland fjord. Polar Biol 23:792-801

Shannon CE, Weaver W (1949) The mathematical theory of communication. University of Illinois Press, Urbana, IL

Sirenko BI (1998) Arctic marine fauna: the results from the expeditions of the Zoological Institute of the Russian Academy of Sciences. Biologiya Morya 24(6):341-350 (in Russian)

Sirotinskaya SV (1975) Logic-informational decisions of geological tasks. Nauka, Moscow (in Russian)

Sorensen TA (1948) A new method of establishing groups of equal amplitude in plant sociology based on similarity of species content and its application to analysis of vegetation on Danish commons. Rgl Dan Vidensk Selsk Biol Skr $5: 1-34$

Stewart PL, Pocklington P, Cunjak RA (1985) Distribution, abundance and diversity of benthic macroinvertebrates on the Canadian continental shelf and slope of southern Davis Strait and Ungava Bay. Arctic 38:281-291

Stoker SW (1981) Benthic invertebrate macrofauna of the eastern Bering/Chukchi continental shelf. In: Hood DW, 
Calder JA (eds) The eastern Bering Sea shelf. Oceanography and resources, Vol 2. US Department of Commerce, Washington, DC, p 1069-1091

Streltzov V (1966) Quantitative distribution of polychaetes in the southern part of the Barent Sea. In: Zelikman EA (ed) Composition and distribution of plankton and benthos in the southern part of the Barents Sea. Nauka, Leningrad, p 71-91

Tereschenko VV, Dvinina EA, Borovaya LI (1985) Informative material on temperature of water in Barents sea. PINRO, Murmansk (in Russian)

Thomson DH (1982) Marine benthos in the eastern Canadian high arctic: multivariate analyses of standing crop and community structure. Arctic 35:61-74

van Veen J (1933) Onderzoek naar het zandtransport von rivieren. Ingenieur 48:151-159

Vinogradov ME, Vedernikov VI, Romankevich EA, Vetrov AA (2000) Some components of the carbon cycle in the

Editorial responsibility: Otto Kinne (Editor),

Oldendorf/Luhe (Germany)
Russian Arctic Sea: primarily production and flux of organic C from the photic layer. Oceanology 40(2): 221-233 (in Russian)

Walker BH (1992) Biodiversity and ecological redundancy. Conserv Biol 6:18-23

Warwick RM, Pearson TH, Ruswahyuni H (1987) Detection of pollution effects on marine macrobenthos: further evaluation of the species abundance biomass method. Mar Biol 95:193-200

Winberg GG (1971) Methods for the estimation of production of aquatic animals. Academic Press, London

Wittakker R (1975) Communities and ecosystems. Macmillan, New York

Zenkevich LA (1927) Quantitative estimation of the bottom fauna of the Pechora region of the Barents and White Seas. Trans Floating Mar Scientific Inst 2:3-64 (in Russian)

Zenkevich L (1963) Biology of the Seas of the USSR. George Allen \& Unwin, London

Submitted: January 16, 2002; Accepted: May 27, 2003

Proofs received from author(s): August 4, 2003 